\title{
Cross cultural and racial comparisons of job satisfaction in a South African hospital setting: Some empirical findings
}

\author{
D.T. Beaty \\ Loyola Marymount University, College of Business, Los Angeles, Ca. 90045 \\ B. de Vries \\ Transport Improvement Services, 25 Lady Anne Ave, Newlands, 7700 Republic of South Africa
}

Accepted 27 January 1987

\begin{abstract}
In this study the authors compare the job satisfaction levels of white and coloured nurses employed at job parity and under similar working conditions. Perceptions of both groups concerning evidence of 25 job characteristics were also obtained. The findings reveal that although coloured nurses identify more job characteristics than their white counterparts, they are not significantly satisfied on intrinsic, extrinsic and overall satisfaction measures. Implications for the advancement of coloured workers into job parity with whites are discussed. Moderating variables that might have influenced these results are also addressed.
\end{abstract}

In hierdie studie tref die outeurs 'n vergelyking tussen die werksbevredigingsvlak van blanke- en kleurlingverpleegsters in dieselfde werksomstandighede. Vyf-en-twintig werkskaraktereienskappe is ook van beide groepe verkry. Alhoewel die kleurlingverpleegsters meer werkskaraktereienskappe as blankeverpleegsters geïdentifiseer het, het die navorsing getoon dat hulle nie noodwendig meer interne, eksterne en algehele werksbevrediging ondervind nie. Implikasies van gelyke werksverdeling tussen blanke- en kleurlingwerkers word bespreek. Faktore wat moontlik die resultate kon beïnvloed het, word ook bespreek.

\section{Introduction}

Blacks and coloureds in the South African work-force generally have poorer job opportunities than whites. The reasons for this are elaborated elsewhere in work conducted by Human \& Hofmeyer (1985). However, the question left unanswered by most investigations is, given the situation where blacks, coloureds and whites are employed under similar conditions, how do the attitudes of blacks and coloureds compare to those of whites. This issue has significant practical implications for the employment and advancement of blacks and coloureds into positions of job parity with whites. For example, assuming that some employers believe that hiring blacks or coloureds into positions of job parity with whites would result in special morale problems, evidence that blacks and whites do not differ in work attitudes, or even that blacks have more favourable attitudes than whites, would perhaps reduce their misgivings. Findings indicating that blacks have less favourable attitudes than whites would also be of practical importance in pointing out areas that need improvement.

Numerous studies have been conducted in the United States which attempt to examine the attitudes and job satisfaction levels of blacks and whites. These include studies which show that blacks have higher occupational aspirations but lower job expectations than whites, are less oriented towards planning for the future, have a lower degree of achievement orientation, and score lower than whites on a variety of psychological tests, even though the differences were frequently confounded by social class (Kirkpatrick, 1973).

U.S. research into white-black job satisfaction levels has revealed that black Certified Public Accountants (Slocum \& Strawser, 1972), black hospital nursing and clerical staff (O'Reilly \& Roberts, 1973) and black civil service and bank employees (Smith, Smith \& Rollo, 1974) reported lower overall satisfaction levels relative to their white co-workers. However, other studies conflict with these results and report findings that show blacks have higher levels of satisfaction than whites at the blue-collar level (Katzwell, Ewen \& Korman, 1974). In support of these findings, Gavin \& Ewen (1974) indicated that black, male, blue-collar employees of a major airline reported higher levels of satisfaction than their white counterparts on all factors except supervision. Brenner \& Fernsten (1984) also reported higher levels of satisfaction among black blue-collar workers relative to white workers employed at the same job level.

In attempting to explain these results, U.S. studies have examined the relative differences between white and black employees regarding job satisfaction, and have advanced some suggestions towards a better conceptualization of these findings.

Moch (1980) suggested two explanations for the causes of racial differences in job satisfaction. They are cultural explanations and structural explanations. Cultural explanations attribute differential satisfaction by race to beliefs, values or psychological states that predispose members of different races to respond differently to their experience in the organization. Jones, James, Bruni \& Sells (1977) pointed out that an individual's frame of reference, based in part upon his or her subcultural membership will influence both the perceptions of the job and the particular aspects seen as satisfying or dissatisfying. Examining the evidence that U.S. blacks score lower on indices such as need for achievement, self-esteem, need for dominance and 
autonomy relative to whites, Katzell, et al. (1974) hypothesized that such motivational differences would tend to decrease the level of satisfaction that blacks experience in their work. These authors suggested that higher job satisfaction levels among blacks relative to whites might be explained by two concepts. The first is referred to as 'relative deprivation' (Davies, 1969), while the other refers to Festinger's (1954) theory of 'social comparison'. According to the first concept, persons perceive a state of relative deprivation compared to either their earlier conditions, or to the conditions of others who serve as a reference group. In a similar vein, Festinger's theory of social comparison postulates, that people have a 'drive' to evaluate their opinions and will tend to do so with those who are judged to be similar to them on salient variables.

Structural explanations attribute differential levels of satisfaction to systematic differences in the way employees of different races are treated by the organization or by their superiors. Kirkpatrick (1973) suggested that differential levels of satisfaction stem from such diverse sources as biased selection procedures and differential assignments to particular types of job. Prejudice from other group members (Pecorrela, 1975) or the predominance of whites in leadership positions (Fox \& Lefkowitz, 1974) are further explanations for race differences in levels of satisfaction.

As far as South African research on job satisfaction variables is concerned, most studies have primarily addressed the issue of Hertzberg's job satisfaction/ dissatisfaction dichotomy. Although Hertzberg (1966) asserted that his theory is valid across cultural, social, economic and political lines and is thus applicable in South Africa, this assertion has been questioned by the research findings of Orpen (1976) and Backer, (1973). These researchers found, inter alia, that job dissatisfaction and job satisfaction variables do not emerge as separate entities on a sample of workers as Hertzberg's theory suggests (Orpen, 1976), and that black workers (possibly because of their occupational, economic and socio-political status) report being predominantly motivated by context factors (Backer, 1973).

However, while these studies have examined the work motives in relation to Hertzberg's motivation-hygiene theory, we could find no South African investigation that has examined the job satisfaction levels among whites, coloureds or blacks who have obtained job parity and are employed under similar conditions of service. Furthermore, this study is different because it is an experiment that eliminates many of the structural variables that might account for variance in job satisfaction by race. In carrying out such an investigation, therefore, Gavin \& Ewen (1974) assert that the validity of job satisfaction findings and jobrelated perceptions between racial groups rests upon comparisons of blacks and whites who have reached structured job parity and are employed under similar working conditions.

This study set out to test and compare the extrinsic, intrinsic and overall job satisfaction levels among South African white and coloured nurses, as well as their perceptions about the extent to which a variety of different characteristics are evident in their jobs. U.S. findings concur that, given their relative deprivation, blacks in the United States expect less from their jobs than whites do (Jones, et al., 1977; Gavin \& Ewen, 1974). These investigations concluded that blacks perceive their jobs and accompanying rewards to be more satisfying than their white counterparts who expect more from their jobs. In this study, we expect to obtain similar findings in South Africa among coloured or black workers relative to their white counterparts (who should expect to receive more from their jobs).

\section{Method}

\section{Participants and Setting}

The South African labour market can be segmented into three broad areas, each associated with different skill levels, employment conditions and racial groups (Fullager, 1986) First, there is a skilled labour sector, where most jobs are held by white workers and are characterized by high wages, adequate working conditions, stable employment, job security and satisfactory promotional prospects. Second, there exists a semi-skilled labour market of coloured and Asian workers of marginal status. Here, jobs are routinized and relatively stable. Third, there is a large unskilled labour group consisting mainly of black workers, where jobs require limited skill and are repetitive, physically demanding and alienating. Wages of workers in this area are low, and working conditions are generally poor.

Given this racial segmentation of work-force levels found in most South African business organizations, the authors could find few corporations that employed a representative number of black and white employees who were working at job parity and under similar conditions of pay and service, and who were willing to be participants in this study.

Therefore, it was decided to approach a large South African hospital where a representative number of coloured and white registered nurses were working at the same level and under similar conditions of service. The hospital administration provided assurances that salary scales were the same across grades regardless of race or sex.

A total of 200 questionnaires were distributed to registered nurses from which a total of 187 were returned. Of these returned questionnaires, 33 (or $17,6 \%$ ) were spoiled or incomplete due to respondent incompletions of the biographical item 'race'. Respondents participated on a voluntary basis and were guaranteed anonymity.

The final sample $(N=154)$, all of whom were female registered nurses, consisted of $55 \%$ white nurses with a mean age of 33,5 years and an average tenure of 8,8 years, while $45 \%$ of the sample were coloured registered nurses with a mean age of 30,9 years and an average tenure of 4,7 years. 


\section{Measures}

First, the participants were asked to indicate how much each of 25 job characteristics were present in their current job. The questionnaire was adopted from one used by Brenner \& Fernsten (1984) and consisted of a five-point scale for each characteristic ranging from five (equals very much) to one (equals none). This scale was reported by Brenner \& Fernsten (1984) to be particularly useful in assessing employee perceptions of job characteristics.

Second, a nine-item questionnaire adopted from one used by Simonetti \& Weitz (1972), that measures intrinsic, extrinsic and overall satisfaction levels was used. This scale was used because it is one of the few that delineates between intrinsic, extrinsic and overall satisfaction levels of respondents. The scale consisted of five response categories for the first eight items, and Question 9, the overall satisfaction measure, had seven response categories. Scores for the first four questions were combined to form an extrinsic (E) factor score; scores for Questions 5 through 8 were combined to form an intrinsic (I) factor score, and Item 9 was a question designed to tap 'overall satisfaction'. Finally, demographic characteristics including education, tenure,

\section{Table 1 Job satisfaction}

\begin{tabular}{|c|c|c|c|c|c|}
\hline \multirow[b]{2}{*}{ Job satisfaction items } & \multicolumn{2}{|c|}{ Coloured } & \multicolumn{2}{|c|}{ White } & \multirow[b]{2}{*}{$T$} \\
\hline & $M$ & $S D$ & $\boldsymbol{M}$ & $S D$ & \\
\hline Extrinsic factors-overall & 2,86 & 1,16 & 2,78 & 1,12 & 0,67 \\
\hline $\begin{array}{l}\text { 1. How satisfied are you with your } \\
\text { job security (steady work)? }\end{array}$ & 2,13 & 0,80 & 2,07 & 0,78 & 0,47 \\
\hline \multicolumn{5}{|l|}{ 2. How satisfied are you with your } & 0,21 \\
\hline \multicolumn{6}{|l|}{ 3. How satisfied are you with your } \\
\hline \multicolumn{6}{|l|}{$\begin{array}{l}\text { 4. How satisfied are you with the } \\
\text { extent to which your job leaves }\end{array}$} \\
\hline sonal or family life? & 3,29 & 1,08 & 3,11 & 1,21 & 1,00 \\
\hline \multicolumn{6}{|l|}{ Intrinsic factors-overall } \\
\hline $\begin{array}{l}\text { 5. How satisfied are you with your } \\
\text { advancement to better jobs } \\
\text { since starting to work for the }\end{array}$ & & & & & \\
\hline hospital? & 2,88 & 1,04 & 3,05 & 1,01 & 0,00 \\
\hline $\begin{array}{l}\text { 6. How satisfied are you with the } \\
\text { freedom you have to adopt }\end{array}$ & & & & & \\
\hline your own approach to the job? & 2,58 & $\mathbf{0 , 8 4}$ & 2,71 & 1,00 & 0,85 \\
\hline $\begin{array}{l}\text { 7. How satisfied are you with the } \\
\text { recognition you get when you }\end{array}$ & & & & & \\
\hline do a good job? & 2,81 & 1,19 & 3,08 & 1,16 & 1,42 \\
\hline 8. How do you like your job-the & & & & & \\
\hline kind of work you do? & 1,69 & 0,87 & 1,73 & 0,77 & 0,23 \\
\hline 9. Overall satisfaction & 3,18 & 1,02 & 3,23 & 0,87 & $\mathbf{0 , 3 8}$ \\
\hline
\end{tabular}

1 = Completely satisfied

5 = completely dissatisfied age and sex were obtained from the respondents. Moch (1980) suggested that these characteristics are likely to be associated with satisfaction.

The data analysis involved four major aspects:

1. An analysis of variance was conducted on the demographic data to ascertain which demographic factors contributed to the variance in the sample.

2. An analysis using $T$ tests was conducted on the group of respondents $(N=33)$ who omitted completing the demographic item 'Race', in order to determine whether there were significant differences between these respondents and those who completed all of the background data.

3. Means and standard deviations were obtained for coloured and white nurses on the extrinsic, intrinsic and overall satisfaction measures and are depicted in Table 1. $T$ tests were used to determine whether the differences between race groups were statistically significant.

4. Job characteristic means and standard deviations were obtained for coloured and white nurses and are

1.Job security
2.Physical working conditions
3.Fringe benefits
4. Leisure time
5.Advancement
6.Freedom
7.Recognition
8. Work itself

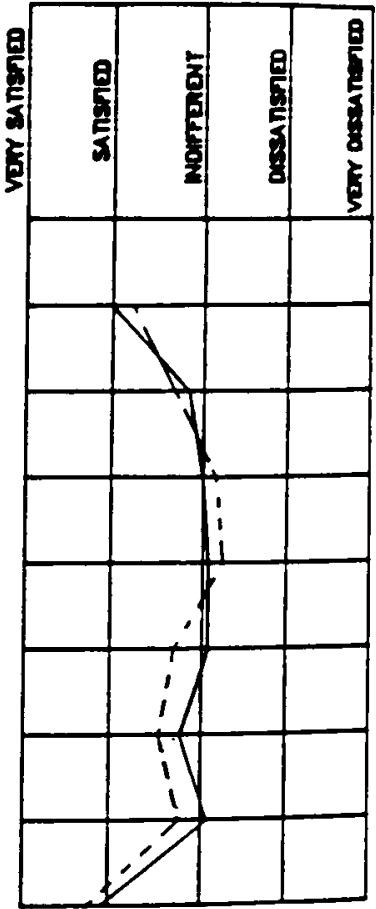

9. Overall satisfaction
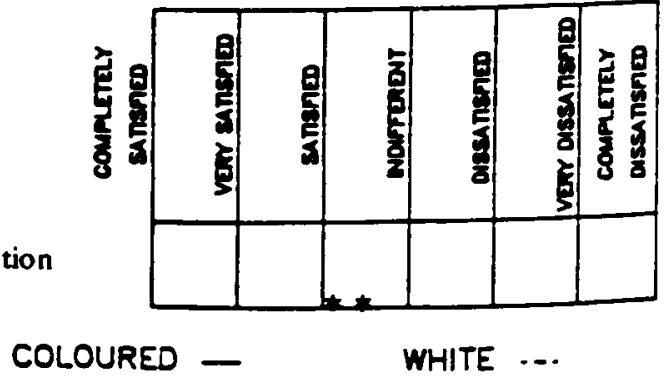

Figure 1 Extrinsic, intrinsic and overall satisfaction levels of coloured and white nurses 
Table 2 Results of job characteristics

\begin{tabular}{|c|c|c|c|c|c|}
\hline \multirow[b]{2}{*}{ Job characteristics } & \multicolumn{2}{|c|}{ Coloured } & \multicolumn{2}{|c|}{ White } & \multirow[b]{2}{*}{$\boldsymbol{T}$} \\
\hline & $\boldsymbol{M}$ & $S D$ & $M$ & $S D$ & \\
\hline 1. Requires originality, creativeness & 3,45 & 1,18 & 2,99 & 1,06 & $2,4^{\bullet}$ \\
\hline 2. Makes use of my specific education background & 3,98 & 1,21 & 3,71 & 1,32 & 1,4 \\
\hline 3. Encourages continued development of knowledge and skills & 4,30 & 0,95 & 3,87 & 1,07 & $2,6^{\circ}$ \\
\hline 4. Is respected by other people & 3,94 & 1,09 & 3,70 & 0,97 & 1,4 \\
\hline 5. Provides job security & 3,85 & 1,09 & 3,82 & 0,97 & 0,2 \\
\hline 6. Provides the opportunity to earn high income & 2,43 & 1,17 & 1,67 & 1,04 & $4,2^{b}$ \\
\hline 7. Makes a social contribution by the work I do & 3,61 & 1,26 & 3,29 & 1,32 & 1,5 \\
\hline 8. Gives me the responsibility for taking the initiative & 4,04 & 0,93 & 3,74 & 1,01 & 1,9 \\
\hline 9. Requires working on problems of importance to the hospital & 3,18 & 1,23 & 2,40 & 1,24 & $3,8^{\mathrm{b}}$ \\
\hline 10. Involves working with friendly associates & 3,94 & 0,86 & 3,89 & 0,79 & 0,4 \\
\hline 11. Provides adequate leisure time off the job & 2,75 & 1,14 & 2,74 & 1,11 & 0,0 \\
\hline 12. Provides change and variety in duties and activities & 3,10 & 0,92 & 3,04 & 1,07 & 0,4 \\
\hline 13. Provides comfortable working conditions & 2,98 & 0,94 & 2,77 & 1,02 & 1,3 \\
\hline 14. Permits advancement to high administrative responsibility & 3,10 & 1,25 & 2,47 & 1,27 & $3,1^{c}$ \\
\hline 15. Permits working independently & 3,47 & 1,18 & 3,24 & 1,37 & 1,1 \\
\hline 16. Rewards good performance with recognition & 3,16 & 1,14 & 2,44 & 1,03 & $4,0^{b}$ \\
\hline 17. Requires supervising others & 4,06 & 0.98 & 3,64 & 1,14 & $2,4^{\bullet}$ \\
\hline 18. Is intellectually stimulating & 4,03 & 1,06 & 3,50 & 1,14 & $2,9^{c}$ \\
\hline 19. Satisfies my cultural and aesthetic interests & 3,45 & 1,18 & 2,57 & 1,14 & $4,6^{b}$ \\
\hline 20. Has clear cut rules and procedures to follow & 4,10 & 0,86 & 3,78 & 0,94 & 2,2 \\
\hline 21. Permits me to work for superiors I admire and respect & 3,72 & 1,06 & $3, \mathbf{3 0}$ & 1,08 & $2,4^{*}$ \\
\hline 22. Permits a regular routine in time and place of work & 4,00 & 0,87 & 3,63 & 1,26 & $2,0^{\circ}$ \\
\hline 23. Requires meeting and speaking with many other people & 4,14 & 0,82 & 3,87 & 1,18 & 1,6 \\
\hline 24. Permits me to develop my own methods of doing the work & 3,37 & 1,22 & 3,29 & 1,19 & 0,4 \\
\hline 25. Provides a feeling of accomplishment & 3,70 & 1,13 & 3,73 & 1,05 & 0,1 \\
\hline
\end{tabular}

iP $<0,05 ;{ }^{b} P<0,01 ;{ }^{c} P<0,00$

5 -very much evident, 1 -no evidence

depicted in Table 2. $T$ tests were used to determine statistical levels of significance between groups.

\section{Results}

An analysis of variance conducted on the demographic data revealed that the item 'race' was the only demographic factor that explained the variance in the job satisfaction and job characteristic findings, except for the characteristic 'job security', where the demographic variable 'age' explained a significant amount of the variation $\left(F_{3,141}=5,02 ; P<0,05\right)$.

As shown in Table 1, no significant differences were found between coloured and white nurses on the extrinsic, intrinsic and overall satisfaction measures. However, when viewed diagrammatically (Figure 1), the findings show a consistent pattern of slightly higher levels of intrinsic satisfaction reported by coloured nurses relative to their white colleagues.

Table 2 indicates that coloured nurses perceived greater evidence for 24 of the $\mathbf{2 5}$ characteristics in their jobs in comparison to white nurses, and 12 of the 25 job characteristics were perceived by coloured nurses to be significantly more evident in their job than those reported by their white colleagues. This pattern is reflected diagramatically in Figure 2.

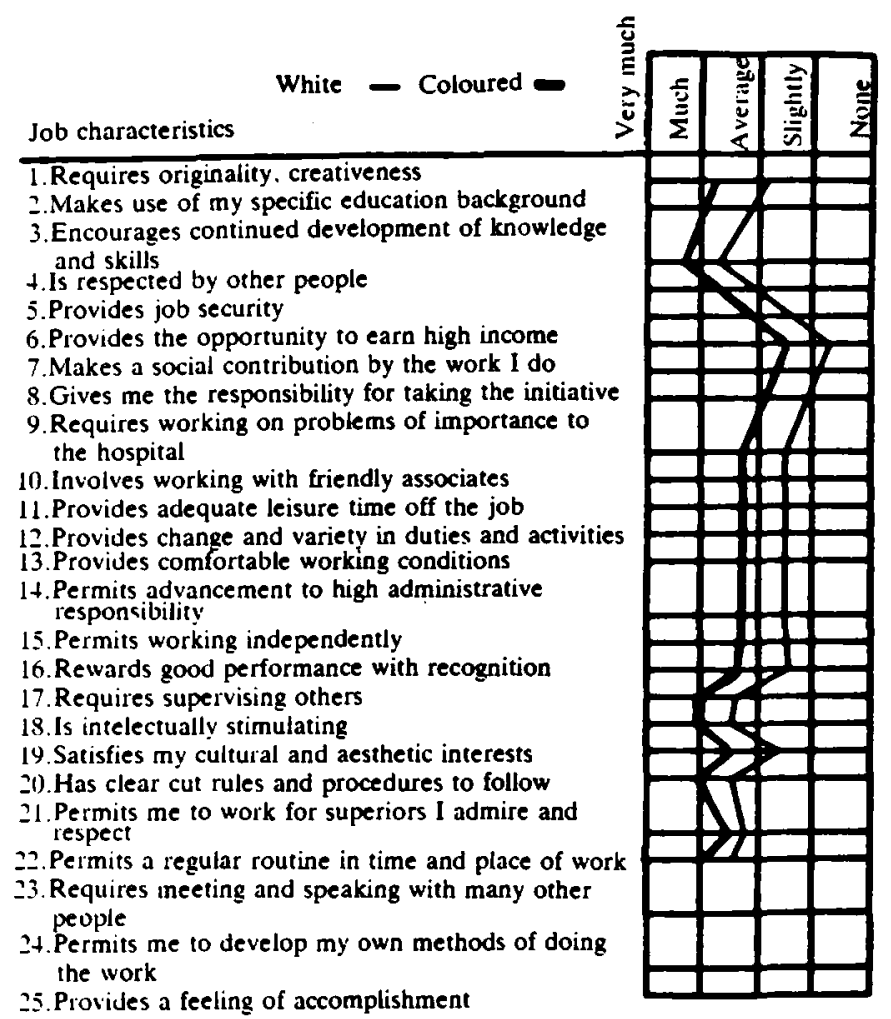

Figure 2 Comparative perceptions of job characteristics between coloured and white nurses 


\begin{tabular}{|c|c|}
\hline INTRINSIC MEASURES & JOB CHARACTERISTICS \\
\hline ADVANCEMENT & $\begin{array}{c}\text { ADVANCEMENT TO } \\
\text { ADMINISTRATIVE } \\
\text { RESPONSIBILITY }\end{array}$ \\
\hline \multirow{3}{*}{ RECOGNITION } & RECOGNITION \\
\hline \multirow{7}{*}{ WORK ITSELF } & ORIGINALITY AND \\
& CREATIVENESS \\
& INTELLECTUALLY \\
& STIMULATING \\
& CLEAR CUT RULES \\
& AIND PFOCEDURES \\
& CULTURAL AND \\
& AESTHETIC INTERESTS \\
& REGULAR ROUTINE \\
\hline
\end{tabular}

Figure 3 Perceptions of job characteristics in relation to intrinsic measures of coloured and white nurses

To examine the consistent pattern of slightly higher intrinsic satisfaction scores indicated by coloured nurses, the job characteristic items on these intrinsic measures were examined. The job characteristics that are significantly different between coloureds and whites are given in Figure 3 , and are grouped according to the intrinsic satisfaction measures. Note that the intrinsic measure 'Freedom' is not included, because there were no significantly different job characteristics found on this factor. In summary, coloured nurses reported slightly higher levels (although these did not reach statistical significance) levels of intrinsic satisfaction than their white counterparts. Furthermore, this result is supported by the finding that coloured nurses perceived significantly more evidence of intrinsic job characteristics than their white counterparts.

Finally, no significant differences were obtained on the extrinsic and intrinsic levels of satisfaction, or on perceptions of job characteristics between the respondents who completed all the biographical data and those who omitted the item of 'Race'. However, a significant difference occurred between those respondents who had completed all the biographical items and those who had omitted the item 'Race'. The latter group reported a significantly lower level of overall satisfaction $(m=4,00)$ than those who had completed all the biographical items $(m=3,20), t_{184}=4,14$, $P<0,001)$.

\section{Discussion and Conclusions}

It should be stressed that the organization involved in this study may not be typical of South African industry in general. That is, this organization manifests a keen interest in equality of pay and working conditions for all races, as well as a willingness to submit to a study of its practices by independent researchers. Therefore, the results of this study are not necessarily applicable to other South African organizations in the private sector.
In addition, the nursing profession historically has attracted members who are more committed to their profession than workers in other occupations, so we would caution against making generalizations across occupation. Also, as we stressed at the outset, the objective of this study was to compare coloureds and whites holding down similar jobs in the same company, so generalizations to comparisons between all coloured workers and all white workers are clearly unwarranted. Furthermore, caution in generalizing these findings to comparisons between all race groups should be exercised. However, inferences can be drawn from coloured worker responses to give us an indication of probable black worker attitudes, because both groups experience deprivation relative to whites in the South African context.

The results indicate that coloureds and whites in similar jobs demonstrate highly similar attitudes to job satisfaction; if anything, coloureds tend to be slightly more satisfied with their jobs. Additional evidence for their consistently higher satisfaction level, is the finding that coloured nurses perceive more evidence of intrinsic job characteristics relative to whites, i.e. advancement opportunities, recognition for a job well done, and meaning from the work itself. This result is interesting when considering Hertzberg's (1966) two-factor theory, which is quite specific in hypothesizing that job-related components are more important to satisfaction, while environmental factors influence job dissatisfaction. Since coloured nurses report more favourable levels of intrinsic satisfaction and more evidence of intrinsic job characteristics relative to their white counterparts, our finding that these favourable attitudes were not sustained in measures of overall satisfaction poses some interesting and speculative observations.

First, questions arise about the extent to which 'life satisfaction' levels moderate the overall job satisfaction responses of coloured nurses relative to their white counterparts. Moch (1980), in a study of job satisfaction variables in an organization located in the southern part of the United States that had a recent history of segregated facilities, found that blacks were less satisfied than whites and concluded that the impact of management on differential satisfaction through internal company policies and practices is likely to be only modest. He suggested that differential satisfaction can be erased through broad racial, cultural and socioeconomic change rather than through conscious management policy. However, our findings show that coloured nurses have similar levels of satisfaction to their white counterparts in a highly segregated society. Our findings contradict those of Moch (1980), which demonstrate lower levels of satisfaction among blacks relative to whites. We question the somewhat pessimistic view he holds about the extent to which management policy can influence job satisfaction, particularly within hospital settings in South Africa. Our results imply that South African organizations can achieve positive gains in satisfaction across race (particularly on measures of intrinsic satisfaction) if they create job. parity and 
remove structural barriers that have a negative impact on equal opportunity for all members. Further research is needed in actual business organizations, however, to further examine and explain these moderating influences.

Second, further research will need to examine the following issues. If South African coloured workers report more favourable levels of intrinsic satisfaction but do not report an increase in overall satisfaction, will these findings be greater for black workers relative to their white colleagues? Since black workers conceivably have higher levels of deprivation relative to coloureds and whites, is it reasonable to assume from our findings that they would respond more positively to intrinsic, extrinsic and overall measures of satisfaction when they are employed in jobs and have working conditions that are on par with whites? Conversely, can one assume that when South African blacks have obtained job parity with whites they will report higher levels of extrinsic and intrinsic satisfaction relative to coloured or white workers? What's more, given the deeper issues surrounding their 'life' concerns, will they report similar or even lower leveis of overall satisfaction than their white or coloured colleagues as some United States studies among black workers suggest? Our findings that indicate $17,6 \%$ of our sample returned spoiled papers by not completing the item 'Race', while also reporting lower levels of overall satisfaction, lead us to speculate about a group who might possess relatively stronger beliefs concerning broader socio-political and cultural issues that relate to race and satisfaction. We can only speculate about how our results might have been influenced if this relatively large group had been included in the overall analysis.

Finally, the results of our study indicate that when coloureds are advanced into positions of job-parity with whites, there appear to be no particular coloured worker 'morale' problems that might lead to special attention by management. Perhaps the most interesting and important finding of this research, is that coloured nurses are so differentially satisfied, even though they are underrepresented among top management. In fact, our findings suggest that misgivings management might have about placing coloured workers on job-parity with their white counter-parts would probably be groundless. Furthermore, white nurses who are on job parity with their coloured colleagues, report no significant levels of job dissatisfaction.

Increasing worker satisfaction is an important management responsibility in South African organizations. Biesheval (1984) points out that overall job satisfaction plays a dynamic and interactive role in the process of performance motivation. He emphasizes that it can also be of value as a state of mind related to the job, an index of good labour relations and morale which could pay off in loyalty, freedom from conflicts, low turnover and absenteeism rates. He concludes that there are considerable indirect benefits to corporations in generating productivity increases from a work-force that has high levels of overall satisfaction.
Our findings suggest that further empirical research needs to be conducted to isolate the variables that moderate levels of satisfaction between racial groups in business settings. We believe that such empirical studies are becoming increasingly important for behavioural scientists to address. These investigations will assist in helping South African corporations and their workers gain greater knowledge as they move towards creating a more equal and just society.

\section{Reforences}

Backer, W. 1973. Motivating black workers. Johannesburg: McGraw-Hill.

Biesheuvel, S. 1984. Work Motivation. Johannesburg: McGraw-Hill.

Bowerman, C.E. \& Campbell, E.Q. 1965. Aspirations of Southern youth: A look at racial comparisons. Transaction, vol. 2, 24.

Brenner, O.C. \& Fernsten, J. 1984. Racial differences in perceived job fulfillment of white collar workers. Perceptual and Motor Skills, vol. 58, 643-646.

Davies, J.C. 1969. The $J$-curve of rising and declining satisfactions as a cause of some great revolutions and a contained rebellion. In Violence in America, Graham, H.D. \& Gurr, T.R. (Eds.). New York: New American Library, 671-709.

Festinger, L. 954. A theory of social comparison processes. Human Relations, vol. 7, 117-140.

Fox, H. \& Lefkowitz, J. 1974. Differential validity: Ethnic group as a moderator in predicting job performance. Pers. Psychol., vol. 27, 209-223.

Fullager, C. 1986. A factor analytic study on the validity of a union commitment scale. J. Appl. Psychol., vol. 71, 129-136.

Gavin, J.F. \& Ewen, R.B. 1974. Racial differences in job attitudes and performance: Some theoretical considerations and empirical findings. Pers. Psychol, vol. 27, 455-464.

Haire, M., Ghiselli, E. \& Porter, L. 1966. Managerial thinking: An international study. New York: Wiley, 1966.

Hertzberg, F. 1966. Work and the nature of man. Ohio: World Publishers.

Human, L. \& Hofmeyer, K. 1985. Black Managers in South African organizations. Johannesburg: Juta and Co.

Katzell, R.A., Ewen, R., \& Korman, A.K. 1974. Job attitudes of black and white workers: Male blue-collar workers in six companies. J. Vocational Behav., vol. 4, 365-376.

Kirkpatrick, J.J. 1973. Occupation, aspiration, opportunity and barriers. In Comparative studies of whites and blacks in the United States. Miller, K.A. \& Dreger, R.M. (Eds.). New York: Seminar Press.

Jones, A.P., James, L.R., Bruni, J.R. \& Sells, S.B. 1977. Black-white differences in work environment perceptions and job satisfaction and its correlates. Pers. Psychol., vol. 30, 5-16.

Moch, M.K. 1980. Racial differences in job satisfaction: testing four common explanations, J. Appl. Psychol., vol. $65,299-306$. 
O'Reilly, C.A., III \& Roberts, K.H. 1973. Job Satisfaction among whites and non-whites: A cross-cultural approach. J. Appl. Psychol., vol. 57, 295-299.

Orpen, C. 1976. Productivity and black workers in South Africa. Johannesburg: Juta.

Pecorrella, P.A. 1975. Predictions of race discrimination in the Navy. (Institute for Social Research. Technical Report). Ann Arbor: University of Michigan.
Simonetti, S.H. \& Weitz, J. 1972. Job satisfaction: Some crosscultural effects. Pers. Psychol., vol. 25, 107-118.

Slocum, J.W., Jr. \& Strawser, R.H. 1972. Racial differences in job attitudes. J. Appl. Psychol., vol. 56, 28-32.

Smith, P.C., Smith, O.W. \& Rollo, J. 1974. Factor structure for blacks and whites of the Job Descriptive Index and its discrimination of job satisfaction. J. Appl. Psychol., vol. $59,99-100$. 